\section{HSE}

Historia Social y de la Educación

Social and Education History
Hipatia Press

www.hipatiapress.com

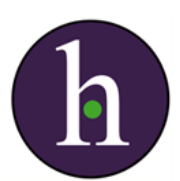

Instructions for authors, subscriptions and further details:

http://hse.hipatiapress.com

\title{
Raças e classes sociais no Brasil
}

Rosimara Silva Correia ${ }^{1}$

1) Universidade Federal de São Carlos (Brasil).

Date of publication: October 23rd 2015

Edition period: October 2015-February 2016

To cite this article: Correia, R. S. (2015). Raças e classes sociais no Brasil [Review of the book]. Social and Education History 4(3), 309-311 doi:10.17583/hse.2015.1741

To link this article: http://dx.doi.org/10.17583/hse.2015.1741

\section{PLEASE SCROLL DOWN FOR ARTICLE}

The terms and conditions of use are related to the Open Journal System and to Creative Commons Attribution License (CC-BY). 


\section{Reviews (I)}

[Ianni] Otávio. (1987). Raças e classes sociais no Brasil. São Paulo: Editora Brasiliense.

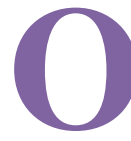

ctávio Ianni, sociologist, Brazilian, graduated by the University of São Paulo, was a researcher dedicated to understanding the social, economic and racial inequalities in the country. The Book " Races and social classes in Brazil", published in 1987, discusses the birth of free labor in Brazilian society during the late nineteenth century, and addresses the economic and social processes responsible for the expelling of enslaved blacks and the advent of capitalism that causes the influx of immigrants to Brazilian urban centers and perpetuates the myth of racial democracy.

In the first part of the book entitled "Blacks and whites in the shaping of society", the author emphasizes that the development of industrial capitalism in Brazil was necessary to overcome the contradictions between commodity and slave; freedom and slavery. Therefore, the abolition of slavery became necessary, but as blacks became free workers, to them remained only lowskilled activities socially and economically wise, that is, manual labor. Therefore, the working class structure in Brazil was permeated by color prejudice, which can not be confused with class prejudice. In this sense, the author illustrates, from real situations, the veiled prejudice, the whitening ideology and the myth of racial democracy.

In this context, the author states that many black people have incorporated the whitening ideology, resulting from a profound action of 
the speeches and practices of whites over blacks. However, there was resistance from politicized actions of blacks who fought for their rights. The claim was for equality not only before the law, for in everyday life there was a socio-economic, ethnic and racial selection of people and, in these selections, blacks were placed in the margins of society: the unemployed, illiterate, marginalized and impoverished.

In the second part, entitled "A Multi-racial society", he discusses the migratory phenomenon of the nineteenth and twentieth century caused by the expansion of capitalism. In political debates of the time it was explicitly stated that immigration, as well as meeting the demands of industrialization, was intended to whiten the country with miscegenation. In this context, the issue of "mulattoes" is addressed with the presence of daily events in which the skin tone, being fairer, enabled them new opportunities for social mobility.

Indigenous communities are also highlighted in the work, focusing on the expropriation of their lands, the aggressive policy of acculturation and denial of rights. He also engages, in this part of the book, into religious diversity as a crucial factor within ideological struggles and its relationship to racial, ethnic and cultural presence in Brazil. In this context, the samba de terreiro is presented from a survey as a means to resist the power and oppression of slaveholders and after the abolition, for the maintenance of group life. The author points out in the country's history the reduced presence of blacks and "mulattoes" in school, and until the moment of publishing of the work, he considered to be countless the barriers to social mobility of this group, therefore, they continue in their great majority in the urban proletariat, alienated as working class and as black race.

In the third part of the book, "The people and the nation", the author retakes some key points that permeated all the book discussions, as the racial democracy myth, the whitening ideology, the embedded racism in Arian theory, the indigenism, and the racial problem in a class society. At this time, he highlights the social struggle of the Brazilian blacks and quotes a variety of writings about the formation of the Brazilian population in social, historical, biological and anthropological perspective, with emphasis on the racial issue.

He encourages and supports the need for new studies and researches that focus on the formation of Brazilian society, in order to shift from common 


\section{HSE - Social and Education History, 4(2) 311}

sense to scientific knowledge, for he considered crucial to undo the ideological plot that involved black people, to overcome the myth of racial democracy, since the emancipation of the peasant worker wasn't enough, as it would not eliminate prejudice and racial discrimination entrenched in Brazilian society. Just over 25 years of its first edition, the book is required reading for anyone studying the Brazilian society, its inequalities and the need to overcome them.

Rosimara Silva Correia

Universidade Federal de São Carlos (Brasil)

marinhasc1@gmail.com 